\title{
A Legacy of Quantitative and Qualitative Data for the Irrigated Violada Area and Conterminous Lands in Aragon, Spain
}

\author{
Juan Herrero *(D) and Carmen Castañeda (D)
}

Estación Experimental de Aula Dei, CSIC, Ave. Montañana 1005, 50059 Zaragoza, Spain; ccastaneda@eead.csic.es

* Correspondence: jhi@eead.csic.es

check for

updates

Citation: Herrero, J.; Castañeda, C A Legacy of Quantitative and Qualitative Data for the Irrigated Violada Area and Conterminous Lands in Aragon, Spain. Agronomy 2021, 11, 799. https://doi.org/ 10.3390/agronomy11040799

Received: 23 February 2021

Accepted: 16 April 2021

Published: 18 April 2021

Publisher's Note: MDPI stays neutral with regard to jurisdictional claims in published maps and institutional affiliations.

Copyright: (c) 2021 by the authors. Licensee MDPI, Basel, Switzerland. This article is an open access article distributed under the terms and conditions of the Creative Commons Attribution (CC BY) license (https:/ / creativecommons.org/licenses/by/ $4.0 /)$.

\begin{abstract}
This paper concerns an old soils report produced using an agronomical approach. The territory studied spans continuous parts of Spain's Huesca and Zaragoza provinces and includes the Violada area. The Spanish Ministry of Agriculture collected the data from 1975 to 1978 through its now-defunct agency, the National Institute for Agrarian Reform and Development (IRYDA), which was in charge of irrigation works in Spain. The surface area studied was 19,393 ha, with 67\% irrigated by inundation and $33 \%$ rainfed at the time of the study. The survey and the related investigations were conducted using state-of-the-art procedures for agronomical research. The purpose was to rate the potential of the lands for irrigated agriculture. The document provides a unique snapshot of the soils and agriculture in the 1970s that can provide a baseline for multitemporal comparisons.
\end{abstract}

Keywords: agriculture; aridity; irrigation; land evaluation; salinity

\section{Introduction}

This paper recalls and summarizes a study of IRYDA [1] involving the agriculture and soils of a $194 \mathrm{~km}^{2}$ demarcation located in the Central Ebro Basin (CEB) (Figure 1).

This study was one of the reports commissioned in the 20th century by the Spanish Ministry of Agriculture for different Spanish regions. Castañeda et al. [2] listed many of these studies, but due to the elimination of IRYDA, they are hard to find or have even been discarded. Their structure and quality can be uneven, but they provide unique documents for tracking the evolution of modern agriculture and for assessing the results of irrigation and other agricultural practices on yields and the environment by comparing the data with other years. Specifically, the IRYDA study [1] is useful for assessing changes in soil salinity over decadal or longer periods. This subject is of paramount environmental and agronomic interest in the dry regions of the world [3], as is the case in the CEB and some other areas of Europe [4]. Soil salinity in the CEB has been and still is a societal concern, as shown by the early references to the problem not only in the local newspapers, but also in scientific and dissemination publications, e.g., Ayers et al. [5] and Cervera-Álvarez [6].

The purpose of this paper is to revive the IRYDA report [1] and to highlight those salient aspects that are significant to understanding how the agriculture and environment evolved in the study area. 


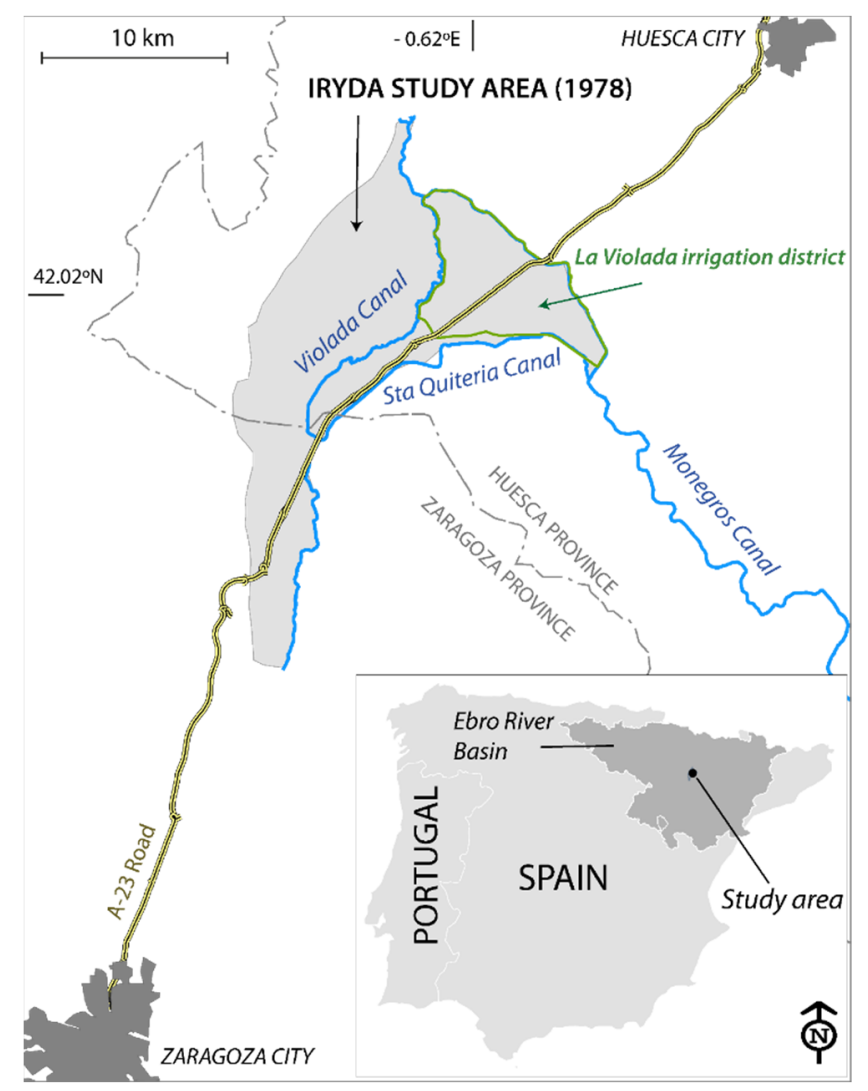

Figure 1. Location of the area studied by IRYDA [1] that includes the Violada irrigation district, outlined in green.

\section{Temporal and Geographic Setting}

In the years 1940-1950, the Spanish Ministry of Agriculture, in concert with the Ministry of Public Works, started the transformation into irrigation of broad areas of the CEB [2], whose aridity was the major constraint to agriculture. IRYDA was the agency responsible for designing, constructing and bringing into production the new irrigation schemes. Since the 1980s, most of these irrigated lands have been gradually modernized by merging plots and transitioning from basin and border irrigation to pressurized irrigation, mainly by solid set or central pivot sprinkling.

The study presented herein is a report of IRYDA [1] on a 19,393-ha demarcation (Figure 1) designated as "Primer tramo de la zona regable de Monegros I" (first section of the irrigable zone of Monegros I). The demarcation belongs to the "Sistema de Riegos del Alto Aragón" (Irrigation System of Alto Aragón), one of the largest irrigation schemes in Europe, which irrigates over 135,300 ha across several irrigation districts (www.riegosaltoaragon.es, accessed on 17 April 2021). Water from the Pyrenees feeds the whole irrigation system, without significant quantities being abstracted from wells or other sources.

Today, the most-studied portion of this demarcation is the Violada irrigation district (Figure 1), in response to the radical changes experienced by agriculture and in particular by irrigation systems. This district was studied early on from the economic point of view of the price of land [7], and raised the call for adopting the advances in irrigation techniques [8].

Several studies were conducted involving the ecology of Violada, such as those mentioned by [9]. More recent studies have been devoted to the soil and water salinity of Violada, as is the case in [10-15]. A comparison of these studies against the data contained in the IRYDA report [1] can highlight the decadal effects of irrigation, as was done for another irrigation area [16]. Until the 1970s, the irrigation technique used in this zone involved the basin and border flooding of leveled fields. The pioneering work of De los 
Ríos [8] stressed the feasibility of pressurized irrigation, a technique that has proven to be both successful and profitable, and which is now common in the irrigated area.

The lands were classified in the report by their potential for irrigated agriculture using the data collected, as detailed below. The scarcity of agronomical studies on the rest of the demarcation confers special value to the IRYDA report [1], because it contains a soil map for both the irrigated and not-irrigated lands.

\section{Methods Used to Study Soil in $\mathbf{1 9 7 8}$ and Resulting Information}

The most advanced methods then available were used. The previous desk study relied on the meager existing data on climate, geology, hydrology and soils, as well as on the interpretation of aerial photograms at scale 1:32,000.

Photo-interpretation and field verification led to the establishment of nine geomorphological units. After interpreting the landscape using aerial photos, the prospectors delineated soil units and opened pits with a backhoe. The soil profiles were described and sampled. The survey included other soil samplings by hand auger. In addition to field tests, classical chemical and physical analyses were performed on the soil samples. Irrigation and phreatic waters were also sampled and analyzed. The measured depth of the water tables ranged from 60 to $135 \mathrm{~cm}$, with a mean of $111 \mathrm{~cm}$. The crops present were recorded and their quality estimated. The report also specifies the number of irrigations-with average doses of $1000 \mathrm{~m}^{3} \mathrm{ha}^{-1}$-applied monthly to each crop: alfalfa, apple, barley, corn, peach, pepper, potato, tomato and wheat. The itineraries in the field allowed recording and appraising of the crops' quality and other agronomical data. The farmer interviews were conducted in the field. The report does not include these interviews, which were used to recommend the crops for each soil unit. Table 1 summarizes the above.

Table 1. Field and laboratory tests in the IRYDA report [1].

\begin{tabular}{lc}
\hline \multicolumn{1}{c}{ Field Tests } & Number \\
\hline Holes opened by hand auger & 97 \\
Pits opened by backhoe, with the soil profile described and sampled & 14 \\
Permeability tests by the auger hole method & 7 \\
Piezometers installed & 12 \\
Farmers' surveys on farm economics and irrigation practices & 25 \\
\hline \multicolumn{1}{c}{ Analyses Conducted at the IRYDA Laboratory in Madrid } \\
\hline Soil samples & 50 \\
Phreatic water samples & 5 \\
Irrigation waters analyzed in 1975 & 4 \\
\hline
\end{tabular}

Table 2 lists some of the information contained in the report. Two observatories close to the study area were used to characterize the climate, Huesca-Monflorite and Pallaruelo de Monegros, because the observatory in Almudévar-the only one located within the study area-had incomplete observation series.

Table 2. Main data in the IRYDA report [1] with the page number where they appear.

\begin{tabular}{lc}
\hline \multicolumn{1}{c}{ Kind of Data } & Page \\
\hline Expected maximum rainfall & 3 \\
Quality of irrigation water & 15 \\
Current crop yields & 17 \\
Soil units in each geomorphic unit & $18-24$ \\
Soil characteristics: depth up to plant growth limiters, texture, surface & $23 b$ \\
stoniness, electrical conductivity (EC) of the phreatic and slope & \\
\hline
\end{tabular}


Table 2. Cont.

\begin{tabular}{lc}
\hline \multicolumn{1}{c}{ Kind of Data } & Page \\
\hline Precipitation deficit & 25 \\
Leaching requirements & 27 \\
Irrigation requirements & 28 \\
Number of irrigations applied monthly to each crop & 29 \\
Soil characteristics affecting their potential under irrigation & $31 \mathrm{~b}$ \\
Description of each land class; surface area of each class and subclass & $32-36$ \\
\hline
\end{tabular}

The report has three annexes. Annex 1 contains five incomplete bibliographic references and Annex 2 contains climatic data and indices. Annex 3 includes:

(a) Descriptions of 14 soil profiles and their classification according to the Soil Taxonomy System [17], as well as their suitability for irrigation according to USBR [18]. All the profiles were Xerochrepts, with five Calcixerollic, five Aquic, three Petrocalcic and one Typic. The classification of the profiles according to their irrigation suitability was: five Class 3sd, four Class1, three Class 3s and 2 Class 2s;

(b) Laboratory determinations for four samples of irrigation water and five phreatic water samples: dry residue, electrical conductivity, $\mathrm{pH}$ and ions as well as derived indices. The average $\mathrm{pH}$ of the irrigation water was 7.95, compared to 7.45 for the phreatic water. The average SAR values were 0.5 and 2 for the irrigation water and phreatic water, respectively. Table 3 summarizes the salt content of the irrigation and phreatic waters;

(c) Chemical analyses and particle size distributions for 50 soil samples from the 14 profiles and six auger holes. Calcium carbonate, with a mean content of $41.2 \%$, was a prominent component of all the soils. This feature, together with the composition of the irrigation water (Table 3), prevented the sodification of the soils by irrigation.

Table 3. Mean composition of the waters analyzed in the IRYDA report [1]: electrical conductivity $\left(\mathrm{EC}, \mathrm{dS} \mathrm{m}^{-1}\right.$ ) and ionic concentrations (meq $\left.\mathrm{L}^{-1}\right)$.

\begin{tabular}{lcccccccc}
\hline & $\mathbf{E C}$ & $\mathbf{C l}^{-}$ & $\mathbf{H C O}_{3}{ }^{-}$ & $\mathbf{S O}_{4}{ }^{2-}$ & $\mathbf{C a}^{2+}+\mathbf{M g}^{2+}$ & $\mathbf{N a}^{+}$ & $\mathbf{K}^{+}$ & $\mathbf{C a}^{2+}$ \\
\hline Irrigation & 0.4 & 2.6 & 2.6 & 0.9 & 3.5 & 0.7 & 0.0 & 2.4 \\
Phreatic & 3.6 & 4.2 & 3.9 & 31.8 & 33.4 & 7.0 & 0.4 & 17.9 \\
\hline
\end{tabular}

Annex 4 shows the four soil permeabilities appraised in April 1978, with a mean of $1.4 \mathrm{~m} \mathrm{day}^{-1}$.

Table 4 lists the plans contained in the report, with a brief overview of the information contained in each plan. Plan No. 1 is an extract from an official topographic map with no date or reference, and plans No. 2 to No. 5 are dated December 1978.

We hope that this note will encourage future research involving multitemporal comparisons of the status of this area. 
Table 4. Plans contained in the IRYDA report [1] with their scale and main information.

\begin{tabular}{ll}
\hline \multicolumn{1}{c}{ Name, Scale } & \multicolumn{1}{c}{ Main Information } \\
\hline $\begin{array}{l}\text { 1. Location, } \\
\text { 1:400,000 }\end{array}$ & Geographical location on an official topographic map. \\
\hline $\begin{array}{l}\text { 2. Current land use, } \\
\text { 1:25,000 }\end{array}$ & $\begin{array}{l}\text { Alternating rainfed cereal crop and fallow, irrigated herbaceous crops, irrigated fruit trees, pine trees, } \\
\text { poplar trees, groves of the river banks, waterlogged areas. }\end{array}$ \\
\hline & $\begin{array}{l}\text { Alluvial with coarse texture, alluvial with fine texture, alluvio-colluvial valley, recent terraces of the } \\
\text { Gállego river with coarse, medium and fine texture or with colluvium, old terraces of the Gállego } \\
\text { 1: Geomorphology, } \\
\text { river, with petrocalcic horizon, dejection fans and colluviums, residual hills, erosion slopes, fine }\end{array}$ \\
& debris slopes, coarse debris slopes, main drainage network. \\
$\begin{array}{l}\text { T. Soils map, } \\
\text { 1:25,000 }\end{array}$ & $\begin{array}{l}\text { marl or gypsum, phreatic water, petrocalcic horizon, gypsum accumulation, non-cemented gravel; } \\
\text { electrical conductivity of the phreatic water. }\end{array}$ \\
\hline & $\begin{array}{l}\text { Irrigable lands; non-irrigable lands; land associations; limiting factors: soil, drainage, slope, only fruit } \\
\text { trees, only sprinkling irrigation; recommended improvements: phreatic water control, salinity } \\
\text { control, crack of the petrocalcic horizon, removal of stones; marked observation sites: augerings, } \\
\text { analyzed augerings, augerings with permeability test, pits with soil analyses, plus permeability test } \\
\text { and plus piezometer. }\end{array}$ \\
\hline 1:25,000 &
\end{tabular}

\section{Conclusions}

Paraphrasing Sumner [19], this paper recovers a piece of forgotten, lost or discarded information that can improve the future. This improvement can be achieved by detecting and interpreting the changes in salinity or other features that are modified by irrigation. In dry climates, this is a major human intervention that changes the traditional agriculture and the whole ecosystem. Hopefully, methodological advances and developments will allow new interpretations and applications - most of them perhaps not yet envisioned-to be derived in years to come using the data from the IRYDA report [1].

Author Contributions: The two authors contributed equally to the work in the paper. Both authors have read and agreed to the published version of the manuscript.

Funding: This work was funded by the Spanish Research Agency (AEI) within the project PCI201809299.

Acknowledgments: This work was funded by the Spanish Research Agency (AEI) within the project PCI2018-09299. The constructive comments of the two reviewers and the Academic Editor improved the text.

Conflicts of Interest: The authors declare no conflict of interest.

\section{References}

1. IRYDA. Estudio de Los Suelos del Primer Tramo de la Zona Regable de Monegros I (Zaragoza-Huesca). Ministerio de Agricultura, Madrid, 46 Pages, 4 Annexes, 5 Planes. 1978. Available online: https:/ / opacaraimagenes.aragon.es/69/61/AHPZ_A_040044_000 7_01.pdf (accessed on 17 April 2021).

2. Castañeda, C.; Herrero, J.; Latorre, B. The vanishing legacy of soil salinity data from irrigated districts: A case study from Spain and a call for action. Adv. Agron. 2020, 161, 325-355. [CrossRef]

3. Nachshon, U. Soil degradation processes: It's time to take our head out of the sand. Geosciences 2021, 11, 2. [CrossRef]

4. Daliakopoulos, I.N.; Tsanis, I.K.; Koutroulis, A.; Kourgialas, N.N.; Varouchakis, A.E.; Karatzas, G.P.; Ritsema, J. The threat of soil salinity: A European scale review. Sci. Total Environ. 2016, 573, 727-739. [CrossRef] [PubMed]

5. Ayers, A.D.; Vázquez, A.; de la Rubia, J.; Blasco, F.; Samplón, S. Saline and sodic soils of Spain. Soil Sci. 1960, 90, 133-138. [CrossRef]

6. Cervera-Álvarez, R. Los suelos salinos de la Depresión del Ebro. Boletín de la Asoc. Nac. de Ing. Agrónomos 1966, 167, 193-199.

7. Jordán de Urriés Azara, F.; de Haro Moreno, C.; Laguna Reñino, M. Dictamen Sobre Los Precios Máximos y Mínimos en Secano Aplicables a Las Clases de Tierra y Aprovechamientos de la Zona de La Violada; Dictamen Mecanografiado Elevado al Ministro de Agricultura, 1951; p. 39. Available online: http:/ /hdl.handle.net/10261/169597 (accessed on 17 April 2021). 
8. De los Ríos Romero, F. El Riego por Aspersión en Los Nuevos Regadíos del Valle del Ebro; Condiciones Aconsejables Para su Instalación; Informe Mecanografiado; Ministerio de Agricultura, Instituto Nacional de Colonización: Zaragoza, España, $1967 ;$ p. 25.

9. Serrano, J.; Bellot, F.; Golley, F. The role of natural vegetation in the biogeochemistry of an agricultural landscape. Acta Oecol. 1992, 13, 569-581.

10. Isidoro, D.; Quílez, D.; Aragüés, R. Environmental impact of irrigation in La Violada District (Spain): I. Salt export patterns. J. Environ. Qual. 2006, 35, 766-775. [CrossRef] [PubMed]

11. Barros, R.; Isidoro, D.; Aragüés, R. Three study decades on irrigation performance and salt concentrations and loads in the irrigation return flows of La Violada irrigation district. Agric. Ecosyst. Environ. 2012, 151, 44-52. [CrossRef]

12. Herrero, J.; Castañeda, C. The success story of irrigation against salinity in Violada, NE Spain. Land Degrad. Dev. 2018, 29, 3039-3049. [CrossRef]

13. Jiménez-Aguirre, M.T.; Isidoro, D. Hydrosaline balance in and nitrogen loads from an irrigation district before and after modernization. Agric. Water Manag. 2018, 208, 163-175. [CrossRef]

14. Jiménez-Aguirre, M.T.; Isidoro, D.; Usón, A. Soil variability in La Violada Irrigation District (Spain): I Delineating soil units for irrigation. Geoderma 2018, 311, 78-90. [CrossRef]

15. Jiménez-Aguirre, M.T.; Isidoro, D.; Usón, A. Soil variability in La Violada Irrigation District (Spain): II Characterizing hydrologic and salinity features. Geoderma 2018, 311, 67-77. [CrossRef]

16. Mora, J.L.; Herrero, J.; Weindorf, D.C. Multivariate analysis of soil salination-desalination in a semi-arid irrigated district of Spain. Geoderma 2017, 291, 1-10. [CrossRef]

17. Soil Survey Staff. Soil Taxonomy: A Basic System of Soil Classification for Making and Interpreting Soil Surveys; Agriculture Handbook; USDA: Washington, DC, USA, 1975; p. 436.

18. USBR. United States Department of the Interior, Bureau of Reclamation Manual, Vol. V Irrigated Land Use. Part. 2 Land Classification; Estrada, A.J., Ed.; Ministerio de Obras Públicas de Venezuela: Caracas, Venezuela, 1963; p. 198.

19. Sumner, M.E. Soil testing and plant analysis: Building a future on our legacy. Commun. Soil Sci. Plant Anal. 2006, 37, 2277-2287. [CrossRef] 